\title{
IMPLIKASI PENERAPAN PERATURAN GUBERNUR NOMOR 42 TAHUN 2017 TERHADAP PENINGKATAN PENERIMAAN PAJAK KENDARAAN BERMOTOR DI SAMSAT MANADO
}

\author{
Meilani Wondal ${ }^{1}$, Linda Lambey ${ }^{2}$, Anneke Wangkar ${ }^{3}$ \\ 1,2,3, Jurusan Akuntansi, Fakultas Ekonomi dan Bisnis, Universitas Sam Ratulangi, Jl. Kampus Bahu, Manado, \\ 95115, Indonesia \\ E-mail : wondal_meilani@yahoo.com
}

\begin{abstract}
The motor vehicle tax amnesty is one of the policies which can be issued by local government to improve its motor vehicle tax revenue. In 2017, local government of North Sulawesi, in this case the Governor of North Sulawesi, issued the Governor Regulation Number 42 Year 2017 about motor vehicle tax amnesty and ownership relocation customs. The purpose of this research is to observe the implication process of applying Governor Regulation Number 42 Year 2017 towards the improvement of motor vehicle tax revenue at SAMSAT Manado. Qualitative research method was used with descriptive analysis method to describe the realization of motor vehicle tax revenue using table and diagram before and after tax amnesty which the conclusion was drawn later. The research outcome showed that motor vehicle tax revenue improved due to tax amnesty program even though its implication was not really considerable only 2.028\% of the total revenue of motor vehicle tax in 2017. Keywords: Motor Vehicle Tax Amnesty, Implication, Motor Vehicle Tax Revenue.
\end{abstract}

\section{PENDAHULUAN}

Pemerintah pusat telah memberikan wewenang kepada setiap daerah untuk mengatur dan menciptakan perekonomian setiap daerah masing-masing dengan adanya otonomi daerah. Menurut Pontoh, Ilat dan Warongan (2017), otonomi daerah adalah hak, wewenang, dan kewajiban daerah otonom untuk mengatur dan mengurus sendiri urusan pemerintahan dan kepentingan masyarakat setempat sesuai dengan peraturan perundang-undangan. Pengembangan suatu daerah bisa disesuaikan oleh pemerintah daerah dengan kepentingan, prioritas, dan potensi daerah tersebut. Dengan demikian diharapakan pemerintah daerah dapat mengoptimalkan pajak daerah dan retribusi daerah sebagai pendapatan asli daerah untuk membiayai pemerintahan dan pembangunan daerah dalam rangka meningkatkan dan memeratakan kesejahteraan masyarakat.

Pajak kendaraan bermotor merupakan salah satu pajak yang memiliki potensi yang besar seiring dengan meningkatnya perekonomian masyarakat dan kemajuan teknologi. Hal ini dapat dibuktikan dengan melihat jumlah kendaraan bermotor yang setiap tahunnya mengalami peningkatan. Sebagai salah satu jenis pajak yang memiliki potensi yang besar, kiranya pajak kendaraan bermotor dapat terus ditingkatkan penerimaannya seiring dengan peningkatan jumlah kendaraan bermotor.

PKB memberikan pemasukan dan pendapatan yang cukup besar dalam PAD SULUT yaitu sebesar $70 \%$ baik yang berasal dari PKB dan BBNKB (Bea Balik Nama Kendaraan Bermotor). Walaupun demikian, belum semua wajib pajak menjalankan kewajibannya. Pada tahun 2016, piutang PKB sampai menembus Rp. 82 miliar. Melihat kondisi ini, pemerintah daerah dalam hal ini Gubernur Sulawesi Utara mengeluarkan Peraturan Gubernur Nomor 42 Tahun 2017 tentang pemberian keringanan PKB dan BBNKB. Diharapkan setelah dikeluarkan kebijakan pemberian keringanan PKB dan BBNKB dapat menambah penerimaan dari sektor pajak dan memberikan kontribusi yang berarti terhadap pendapatan asli daerah Sulut. 


\section{TINJAUAN PUSTAKA}

Konsep Akuntansi. Menurut Hery (2014:1), akuntansi secara umum dapat didefinisikan sebagai sebuah sistem informasi yang memberikan laporan kepada para pengguna informasi akuntansi atau kepada pihak-pihak yang memiliki kepentingan (stakeholders) terhadap hasil kinerja dan kondisi perusahaan. Akuntansi adalah proses dari transaksi yang dibuktikan dengan faktur, lalu dari transaksi dibuat jurnal, buku besar, neraca lajur, kemudian akan menghasilkan informasi dalam bentuk laporan keuangan (Sujarweni, 2015:3).

Akuntansi Perpajakan. Akuntansi pajak menurut Supriyanto (2011:2-3) adalah suatu proses pencatatan, penggolongan dan pengikhtisaran suatu transaksi keuangan kaitannya dengan kewajiban perpajakan dan diakhiri dengan pembuatan laporan keuangan fiskal sesuai dengan ketentuan dan peraturan perpajakan yang terkait sebagai dasar pembuatan surat pemberitahuan.

Dasar Perpajakan. Undang-Undang Nomor 16 Tahun 2009 tentang Ketentuan Umum dan Tata Cara Perpajakan (KUP) menyatakan Pajak adalah kontribusi wajib kepada negara yang terutang oleh orang pribadi atau badan yang bersifat memaksa berdasarkan Undang-Undang, dengan tidak mendapat imbalan secara langsung dan digunakan untuk keperluan negara bagi sebesar-besarnya kemakmuran rakyat. Menurut Waluyo (2013 : 3), pajak adalah iuran wajib berupa uang atau barang yang dipungut oleh penguasa berdasarkan norma-norma hukum, guna menutup biaya produksi barang-barang dan jasa-jasa kolektif dalam mencapai kesejahteraan umum.

Tujuan dan Fungsi Pajak. Menurut Nuskel yang dikutip dalam Rahayu (2010 : 37), secara umum tujuan diberlakukannya pajak antara lain adalah sebagai berikut : (1) untuk mencapai kondisi meningkatnya ekonomi suatu negara; (2) untuk membuat konsumsi dan dengan demikian mentransfer sumber dari konsumsi; (3) untuk mendorong tabungan dan menanamkan modal; (4) untuk mentransfer sumber dari masyarakat ke tangan pemerintah sehingga memungkinkan adanya investasi pemerintah; (5) untuk memodifikasi pola investasi; (6) untuk mengurangi ketimpangan ekonomi; dan (7) untuk membatasi surplus ekonomi. Mardiasmo (2016 : 4) menyatakan bahwa ada dua fungsi pajak, yaitu sebagai berikut :

1. Fungsi Anggaran (Budgetair). Pajak berfungsi sebagai salah satu sumber dana bagi pemerintah untuk membiayai pengeluaran-pengeluarannya.

2. Fungsi Mengatur (Regulerend). Pajak berfungsi sebagai alat untuk mengatur atau melaksanakan kebijaksanaan pemerintahan dalam bidang sosial dan ekonomi.

Seiring perkembangan, Burton (2013 : 13) menyatakan dua tambahan fungsi pajak yaitu:

1. Fungsi Demokrasi Penjelmaan. Fungsi yang merupakan salah satu atau wujud sistem gotong royong, termasuk kegiatan pemerintahan dan pembangunan demi kemaslahatan manusia.

2. Fungsi Redistribusi. Fungsi yang lebih menekankan pada unsur pemerataan dan keadilan dalam masyarakat.

Pengelompokan Pajak. Mardiasmo (2016 : 7-8) menyatakan bahwa ada tiga pengelompokan pajak, yaitu sebagai berikut : (1) menurut Golongan, yaitu pajak langsung dan pajak tidak langsung; (2) menurut Sifat, yaitu pajak subjektif dan pajak objektif; dan (3) menurut Lembaga Pemungut, yaitu pajak pusat dan pajak daerah.

Sistem Pemungutan Pajak. Menurut Mardiasmo (2011 : 7), sistem pemungutan pajak dibedakan menjadi berikut ini.

1. Official Assessment System, adalah suatu sistem pemungutan yang memberi wewenang kepada pemerintah (fiskus) untuk menentukan besarnya pajak yang terutang oleh wajib pajak.

2. Self Assessment System, adalah suatu sistem pemungutan pajak yang memberi wewenang kepada wajib pajak untuk menentukan sendiri besarnya pajak yang terutang. 
3. With Holding System, adalah suatu sistem pemungutan pajak yang memberi wewenang kepada pihak ketiga (bukan fiskus dan bukan wajib pajak yang bersangkutan) untuk menentukan besarnya pajak terutang oleh wajib pajak.

Pajak Daerah. Menurut Resmini yang dikutip oleh Hasannudin dan Wokas (2014), pajak daerah adalah pajak yang dipungut oleh pemerintah daerah baik daerah tingkat I (pajak provinsi) maupun pajak daerah tingkat II (pajak kabupaten/kota) dan digunakan untuk membiayai rumah tangga daerah masing-masing. Pajak daerah menurut Pasal 2 ayat (1) dan (2) UU Nomor 28 Tahun 2009 terbagi atas 2 (dua) yaitu pajak provinsi yang terdiri 5 (lima) jenis pajak yaitu pajak kendaraan bermotor, bea balik nama kendaraan bermotor, pajak bahan bakar kendaraan bermotor, pajak air permukaan dan pajak rokok. Dan pajak kebupaten/kota terdiri dari 11 (sebelas) jenis pajak yaitu pajak hotel, pajak restoran, pajak hiburan, pajak reklame, pajak penerangan jalan, pajak mineral bukan logam dan batuan, pajak parkir, pajak air tanah, pajak sarang burung walet, pajak bumi dan bangunan perdesaan dan perkotaan, dan bea perolehan hak atas tanah dan bangunan.

Pajak Kendaraan Bermotor. Menurut Samudra yang dikutip oleh Inggrini, Morasa dan Mawikere (2018), kendaraan bermotor adalah setiap kendaraan yang digerakkan oleh peralatan teknik yang ada pada kendaraan dan biasanya digunakan untuk orang dan barang selain daripada kendaraan yang berjalan di atas rel. Undang-Undang Nomor 28 Tahun 2009 tentang Pajak Daerah dan Retribusi Daerah, menjelaskan pajak kendaraan bermotor adalah pajak atas kepemilikan dan/atau penguasaan kendaraan bermotor. Subjek pajak kendaraan bermotor menurut Pasal 4 Undang-Undang Nomor 28 Tahun 2009 adalah Orang Pribadi atau Badan yang memiliki dan/atau menguasai kendaraan bermotor. Wajib pajak kendaraan bermotor adalah Orang Pribadi atau Badan yang memiliki kendaraan bermotor. Dalam hal wajib pajak Badan, kewajiban perpajakannya diwakili oleh pengurus atau kuasa Badan tersebut. Yang menjadi objek pajak kendaraan bermotor adalah kepemilikan dan/atau penguasaan kendaraan bermotor. Dasar pengenaan pajak kendaraan bermotor adalah hasil perkalian dari 2 unsur pokok yaitu Nilai Jual Kendaraan Bermotor (NJKB) dan bobot yang mencerminkan secara relatif tingkat kerusakan jalan dan/atau pencemaran lingkungan akibat penggunaan kendaraan bermotor. Besarnya tarif PKB berdasarkan Pasal 7 Nomor 7 Peraturan Daerah Provinsi Sulawesi Utara Tahun 2011 tentang Pajak Daerah ditetapkan sebagaimana berikut ini:

1. Untuk kepemilikan kendaraan bermotor pertama sebesar $1,5 \%$.

2. Untuk kepemilikan kendaraan bermotor kedua dan seterusnya ditetapkan secara progresif, yaitu: (a) Kendaraan kepemilikan kedua sebesar 2\%; (b) Kendaraan kepemilikan ketiga sebesar 2,5\%; (c) Kendaraan kepemilikan keempat sebesar 3\%; dan (d) Kendaraan kepemilikan kelima dan seterusnya sebesar 3,5\%.

3. Untuk angkutan umum sebesar $1 \%$ dan tarif untuk ambulans, pemadam kebakaran, sosial keagamaan, lembaga sosial dan keagamaan, Pemerintah/TNI/POLRI, Pemerintah Daerah ditetapkan sebesar $0,5 \%$.

4. Untuk alat-alat berat dan alat-alat besar ditetapkan sebesar $0,2 \%$.

5. Untuk kendaraan bermotor di atas air ditetapkan sebesar $1,5 \%$.

Secara umum, perhitungan PKB adalah sesuai dengan rumus berikut ini:

$$
\begin{array}{r}
\text { PKB Terutang }=\text { Tarif Pajak } \times \text { Dasar Pengenaan Pajak } \\
=\text { Tarif Pajak } x \text { (NJKB } \times \text { Bobot })
\end{array}
$$

Keringanan Pajak Kendaraan Bermotor. Keringanan PKB adalah suatu tindakan yang dilakukan oleh pemerintah yang berwenang untuk mendorong para wajib pajak yang telah lama tidak membayarkan kewajibannya dalam membayar pajak kendaraan bermotor dengan cara mengurangi pokok pajak serta pembebasan denda pajak kendaraan bermotor. 
Dalam rangka mendorong kesadaran masyarakat dan meningkatkan kepatuhan wajib pajak untuk memenuhi kewajibannya membayar PKB dan BBNKB, Pemerintah Daerah Sulawesi Utara mengeluarkan Peraturan Gubernur Sulawesi Utara Nomor 42 Tahun 2017 yang membahas tentang Tata Cara dan Besarnya Pemberian Keringanan, Pengurangan Pokok serta Pembebasan Denda Pajak Kendaraan Bermotor dan Bea Balik Nama Kendaraan Bermotor. Program keringanan PKB dan BBNKB ini berlaku sejak tanggal 12 September 2017 sampai tanggal 15 Desember 2017. Untuk memperoleh keringanan, pengurangan pokok serta pembebasan denda PKB dan BBNKB sesuai dengan Peraturan Gubernur Nomor 42 Tahun 2017, wajib pajak harus mengajukan permohonan secara tertulis kepada Gubernur Sulawesi Utara melalui Kepala BP2RD Sulawesi Utara, yang berisikan data seperti nama wajib pajak, pekerjaan wajib pajak, alamat wajib pajak, alasan-alasan yang jelas dan ditandatangani wajib pajak. Permohonan tersebut harus dilampirkan dengan persyaratan formal seperti foto copy KTP/ keterangan kependudukan, foto copy SKPD PKB, dan foto copy BPKB. Besarnya pemberian keringanan, pengurangan pokok serta pembebasan denda PKB sesuai dengan Pasal 3 Peraturan Gubernur Nomor 42 Tahun 2017 adalah sebagai berikut:

1. Pokok PKB untuk tahun berjalan dibayar seluruhnya.

2. Pokok PKB yang lewat jatuh tempo belum dibayar, dihitung menurut umur atau lamanya tidak membayar yaitu :

a. Untuk tahun ke-2 diberikan keringanan dan pengurangan sebesar 50\% dari pokok pajak dan pembebasan denda $100 \%$;

b. Untuk tahun ke-3 diberikan keringanan dan pengurangan sebesar $60 \%$ dari pokok pajak dan pembebasan denda $100 \%$;

c. Untuk tahun ke-4 diberikan keringanan dan pengurangan sebesar $70 \%$ dari pokok pajak dan pembebasan denda $100 \%$;

d. Untuk tahun ke-5 diberikan keringanan dan pengurangan sebesar $80 \%$ dari pokok pajak dan pembebasan denda 100\%; dan

e. Untuk tahun ke-6 dan seterusnya diberikan pembebasan pokok pajak dan denda $100 \%$.

Penelitian Terdahulu. Beberapa penelitian terdahulu yang penulis jadikan sebagai bahan pertimbangan ketika melakukan penelitian di Samsat Manado. Penelitian yang dilakukan oleh Ekasari dan Akbari (2017) dengan judul tingkat efektivitas penerapan pemutihan pajak kendaraan bermotor terhadap peningkatan penerimaan pajak daerah. Tujuan penelitian ini adalah untuk melihat tingkat efektivitas penerapan pemutihan pajak kendaraan bermotor terhadap peningkatan penerimaan pajak daerah. Hasil penelitian menunjukkan tingkat efektivitas penerimaan PKB tahun 2016 pada UPT Dinas Pendapatan Provinsi Jawa Timur Malang Utara dan Batu Kota sudah efektif, karena melebihi $100 \%$ yaitu sebesar 108,18\%. Apsari (2012) dengan judul pengaruh insentif pajak BBNKB terhadap jumlah wajib pajak kendaraan bermotor yang terdaftar di Surabaya Barat, dengan tujuan penelitian untuk mengetahui pengaruh pemberian insentif pajak terhadap minat wajib pajak dalam mendaftarkan diri sebagai wajib pajak kendaraan bermotor di daerah Surabaya Barat. Hasil penelitian menunjukkan pemberian insentif pajak BBNKB tidak berpengaruh terhadap jumlah wajib pajak kendaraan bermotor yang terdaftar pada awal bulan pemberlakuan kebijakan insentif pajak yaitu bulan April dan Mei, akan tetapi pada bulan Juni dan Juli menampakkan adanya pengaruh yang signifikan.

\section{METODE PENELITIAN}

Jenis Penelitian. Jenis penelitian yang digunakan dalam penelitian ini adalah penelitian kualitatif. Menurut Bogdan dan Taylor yang dikutip oleh Sujarweni (2015), penelitian kualitatif adalah salah satu prosedur penelitian yang menghasilkan data deskriptif berupa ucapan atau tulisan dan perilaku orang-orang yang diamati. Jadi, dalam penelitian ini 
peneliti akan membandingkan realisasi penerimaan pajak kendaraan bermotor di UPTD Samsat Manado sebelum dan saat penerapan Peraturan Gubernur Nomor 42 Tahun 2017 untuk melihat implikasi dari penerapan Peraturan Gubernur Nomor 42 Tahun 2017 terhadap peningkatan penerimaan pajak kendaraan bermotor di UPTD Samsat Manado.

Tempat dan Waktu Penelitian. Penelitian dilakukan pada UPTD Samsat Manado, yang beralamat di Jalan 17 Agustus No. 123 Manado, Tanjung Batu, Wanea, Kota Manado, Sulawesi Utara. Waktu penelitian di mulai pada bulan Maret-Juni 2018.

\section{Jenis Data Penelitian}

1. Data kualitatif dalam penelitian ini adalah profil UPTD Samsat Manado, Peraturan Gubernur Nomor 42 Tahun 2017 dan hasil wawancara.

2. Data kuantitatif dalam penelitian ini adalah realisasi keringanan PKB berdasarkan Peraturan Gubernur Nomor 42 Tahun 2017 dan realisasi penerimaan PKB tahun 2016 dan 2017 di UPTD Samsat Manado.

Sumber Data. Sumber data dari penelitian ini adalah data primer. Data primer yaitu data yang langsung dipeoleh dari objek penelitian dan dalam penelitian ini data primer dipeoleh dari UPTD Samsat Manado. Data primer dalam penelitian ini adalah data atau informasi yang diperoleh dari hasil wawancara, profil instansi UPTD Samsat Manado, realisasi keringanan PKB berdasarkan Peraturan Gubernur Nomor 42 Tahun 2017 dan realisasi penerimaan PKB tahun 2016 dan 2017 di UPTD Samsat Manado.

Metode Pengumpulan Data. Metode pengumpulan data yang dilakukan dalam penelitian ini ada dua cara yaitu wawancara dan dokumentasi. Wawancara yaitu cara mengumpulkan data dengan melakukan tanya jawab secara langsung dengan pihak-pihak terkait seperti Kepala Seksi Pelayanan Sengketa DLL PAD dan Kepala Seksi Pelayanan PKB, BBNKB dan PAP. Dan dokumentasi yaitu mengumpulkan bahan-bahan yang tertulis berupa data yang diperoleh dari objek penelitian yaitu UPTD Samsat Manado seperti data realisasi program keringanan berdasarkan Peraturan Gubernur Nomor 42 Tahun 2017 dan realisasi penerimaan PKB tahun 2016 dan tahun 2017.

Metode dan Proses Analisis. Metode analisis yang digunakan dalam penelitian adalah metode analisis deskriptif yaitu suatu metode pembahasan yang sifatnya menguraikan, menggambarkan, membandingkan dan menerangkan suatu data atau keadaan yang bertujuan untuk mendapatkan gambaran yang lebih jelas dan terperinci mengenai suatu keadaan berdasarkan informasi yang telah didapat, kemudian dikumpulkan sehingga didapat informasi yang diperlukan untuk menganalisa masalah yang ada. Peneliti membandingkan jumlah penerimaan PKB sebelum dan sementara diberlakukannya Peraturan Gubernur Nomor 42 Tahun 2017 baik dari segi jumlah realisasi maupun dari segi jumlah objek pajak atau unit kendaraan bermotor yang membayar PKB, dan selanjutnya diuraikan berdasarkan hasil wawancara. Pada tahap akhir peneliti menarik kesimpulan berdasarkan proses analisis yang telah dilakukan.

\section{HASIL PENELITIAN DAN PEMBAHASAN}

\subsection{Hasil Penelitian}

Pajak kendaraan bermotor dipungut dengan sistem official assessment system yang adalah salah satu sistem pemungutan pajak yang memberi wewenang kepada pemerintah untuk menentukan besarnya pajak yang terutang. Besarnya PKB yang terutang dihitung dengan cara mengalikan tarif pajak yaitu $1,5 \%$ dengan dasar pengenaan pajak dan dasar pengenaan pajak diperoleh dari NJKB yang dikalikan dengan bobot. Di Sulawesi Utara pajak kendaraan bermotor dan bea balik nama kendaraan bermotor merupakan pajak daerah yang memberikan kontribusi terbesar yang mencapai $70 \%$ dari PAD. Oleh karena itu pemerintah terus berusaha untuk meningkatkan penerimaan dari sektor pajak ini yang salah satunya dengan mengeluarkan Peraturan Gubernur Nomor 42 Tahun 2017 tentang pemberian 
keringanan PKB dan BBNKB. Program keringanan berlaku pada tanggal 12 September hingga 15 Desember 2017. Adapun alur atau mekanisme permohonan keringanan pajak/denda pajak kendaraan bermotor adalah sebagai berikut :

1. Wajib Pajak bermohon ke UPTD Samsat untuk mendapatkan keringanan pajak dan penghapusan denda pajak dengan membawa surat permohonan dan melampirkan foto copy KTP/keterangan kependudukan, foto copy STNK dan SKPD PKB terakhir, dan foto copy BPKB sebagai persyaratan.

2. UPTD melakukan seleksi berkas (kelengkapan) berupa KTP, STNK dan SKPD PKB serta BPKB.

3. UPTD melakukan penetapan PKB, BBNKB, denda PKB dan denda BBNKB.

4. Kepala UPTD mengusulkan berkas ke Kantor Pusat/BP2RD (Bidang Pajak).

5. Bidang Pajak melakukan verifikasi berkas dan penetapan keringanan pajak dan denda pajak kendaraan.

6. Kepala Badan menandatangani berkas yang sudah terverifikasi dalam bentuk Surat Keputusan (SK) pengurangan dan pembebasan tunggakan PKB dan BBNKB.

7. UPTD menjemput berkas (SK) untuk diberikan kepada Wajib Pajak (WP).

8. Wajib Pajak (WP) melakukan pembayaran sesuai dengan Surat Keputusan (SK) dari Kepala Badan.

Di bawah ini adalah realisasi dari program keringanan PKB berdasarkan Peraturan Gubernur Nomor 42 Tahun 2017.

Tabel 4.1 Realisasi Penerimaan Keringanan PKB Tahun 2017 di UPTD Samsat Manado

\begin{tabular}{|c|c|c|c|c|c|c|}
\hline \multirow{3}{*}{ Berdasarkan } & \multicolumn{4}{|c|}{ JENIS KENDARAAN BERMOTOR } & \multirow{2}{*}{\multicolumn{2}{|c|}{ JUMLAH }} \\
\hline & \multicolumn{2}{|c|}{ RODA 2} & \multicolumn{2}{|c|}{ RODA 4} & & \\
\hline & UNIT & Rp. & UNIT & Rp. & UNIT & Rp. \\
\hline $\begin{array}{c}\text { SK Yang } \\
\text { Dikeluarkan }\end{array}$ & 424 & 197.518 .896 & 1.063 & 3.368 .815 .868 & 1.487 & 3.566.334.764 \\
\hline $\begin{array}{c}\text { Realisasi SK } \\
\text { Yang } \\
\text { Dikeluarkan }\end{array}$ & 291 & 118.873 .996 & 900 & 2.807.658.915 & 1.191 & 2.926.532.911 \\
\hline $\begin{array}{l}\text { Yang Tidak } \\
\text { Membayar }\end{array}$ & 133 & 78.644 .900 & 163 & 561.156 .953 & 296 & 639.801 .853 \\
\hline
\end{tabular}

Sumber: UPTD Samsat Manado 


\subsection{Pembahasan}

4.2.1. Realisasi Penerimaan PKB Tahun 2016

Tabel 4.2 Realisasi Penerimaan PKB Tahun 2016 di UPTD Samsat Manado

\begin{tabular}{|c|c|c|c|c|}
\hline \multirow{3}{*}{ Bulan } & \multirow{3}{*}{ Unit } & PKB & Persentase & $\begin{array}{l}\text { Persentase } \\
\text { Kumulatif }\end{array}$ \\
\hline & & Rp. 127.170.521.200 & \multirow{2}{*}{$3=2 /$ Realisasi $* 100$} & \multirow{2}{*}{$4=\Sigma 3$} \\
\hline & & 2 & & \\
\hline Januari & 14.135 & Rp. 11.861.388.265 & $8,85 \%$ & $8,85 \%$ \\
\hline Februari & 12.371 & Rp. 10.283.100.920 & $7,68 \%$ & $16,53 \%$ \\
\hline Maret & 13.852 & Rp.11.909.045.840 & $8,89 \%$ & $25,41 \%$ \\
\hline April & 13.314 & Rp. 11.584.672.838 & $8,65 \%$ & $34,06 \%$ \\
\hline Mei & 12.479 & Rp. 11.397.030.733 & $8,51 \%$ & $42,57 \%$ \\
\hline Juni & 13.474 & Rp. 11.906.563.350 & $8,89 \%$ & $51,45 \%$ \\
\hline Juli & 11.190 & Rp. 9.461.394.800 & $7,06 \%$ & $58,52 \%$ \\
\hline Agustus & 13.730 & Rp. 11.209.281.712 & $8,37 \%$ & $66,88 \%$ \\
\hline September & 13.366 & Rp. 10.929.487.752 & $8,16 \%$ & $75,04 \%$ \\
\hline Oktober & 13.406 & Rp. 11.572.736.123 & $8,64 \%$ & $83,68 \%$ \\
\hline November & 13.628 & Rp. 11.260.453.908 & $8,40 \%$ & $92,08 \%$ \\
\hline Desember & 12.142 & Rp. 10.603.857.986 & $7,91 \%$ & $100 \%$ \\
\hline Jumlah & 157.087 & Rp. 133.979.014.227 & $100 \%$ & $100 \%$ \\
\hline \multicolumn{3}{|c|}{ Pencapaian Target } & \multicolumn{2}{|c|}{$105,35 \%$} \\
\hline
\end{tabular}

Sumber : UPTD Samsat Manado

\subsubsection{Realisasi Penerimaan PKB Tahun 2017}

Tabel 4.3 Realisasi Penerimaan PKB Tahun 2017 di UPTD Samsat Manado

\begin{tabular}{|c|c|c|c|c|}
\hline \multirow{2}{*}{ Bulan } & \multirow{2}{*}{ Unit } & PKB & Persentase & $\begin{array}{l}\text { Persentase } \\
\text { Kumulatif }\end{array}$ \\
\hline & & $\begin{array}{c}\text { Rp. 140.246.783.336 } \\
2\end{array}$ & $3=2 /$ Realisasi $* 100$ & $4=\Sigma 3$ \\
\hline Januari & 14.144 & Rp 12.478.360.347 & $8,65 \%$ & $8,65 \%$ \\
\hline Februari & 11.196 & Rp 10.392.521.425 & $7,20 \%$ & $15,85 \%$ \\
\hline Maret & 13.844 & Rp. 12.731.508.725 & $8,82 \%$ & $24,67 \%$ \\
\hline April & 11.549 & Rp. 11.357.242.275 & $7,87 \%$ & $32,54 \%$ \\
\hline Mei & 12.906 & Rp. 13.060.345.750 & $9,05 \%$ & $41,59 \%$ \\
\hline Juni & 10.013 & Rp. 9.334.233.247 & $6,47 \%$ & $48,06 \%$ \\
\hline Juli & 14.433 & Rp. 13.042.678.778 & $9,04 \%$ & $57,10 \%$ \\
\hline Agustus & 14.024 & Rp. 13.161.873.325 & $9,12 \%$ & $66,22 \%$ \\
\hline September & 12.264 & Rp. 11.236.873.121 & $7,79 \%$ & $74,01 \%$ \\
\hline Oktober & 13.995 & Rp. 12.469.620.426 & $8,64 \%$ & $82,65 \%$ \\
\hline November & 14.639 & Rp. 13.670.190.565 & $9,47 \%$ & $92,12 \%$ \\
\hline Desember & 11.868 & Rp. 11.379.024.576 & $7,88 \%$ & $100 \%$ \\
\hline Jumlah & 154.875 & Rp. 144.314.472.560 & $100 \%$ & $100 \%$ \\
\hline \multicolumn{3}{|c|}{ Pencapaian Target } & \multicolumn{2}{|c|}{$102,9 \%$} \\
\hline
\end{tabular}

Sumber: UPTD Samsat Manado 


\subsection{3}

Implikasi Program Keringanan Terhadap Peningkatan Penerimaan PKB

Grafik 4.5 Realisasi Penerimaan PKB di UPTD Samsat Manado

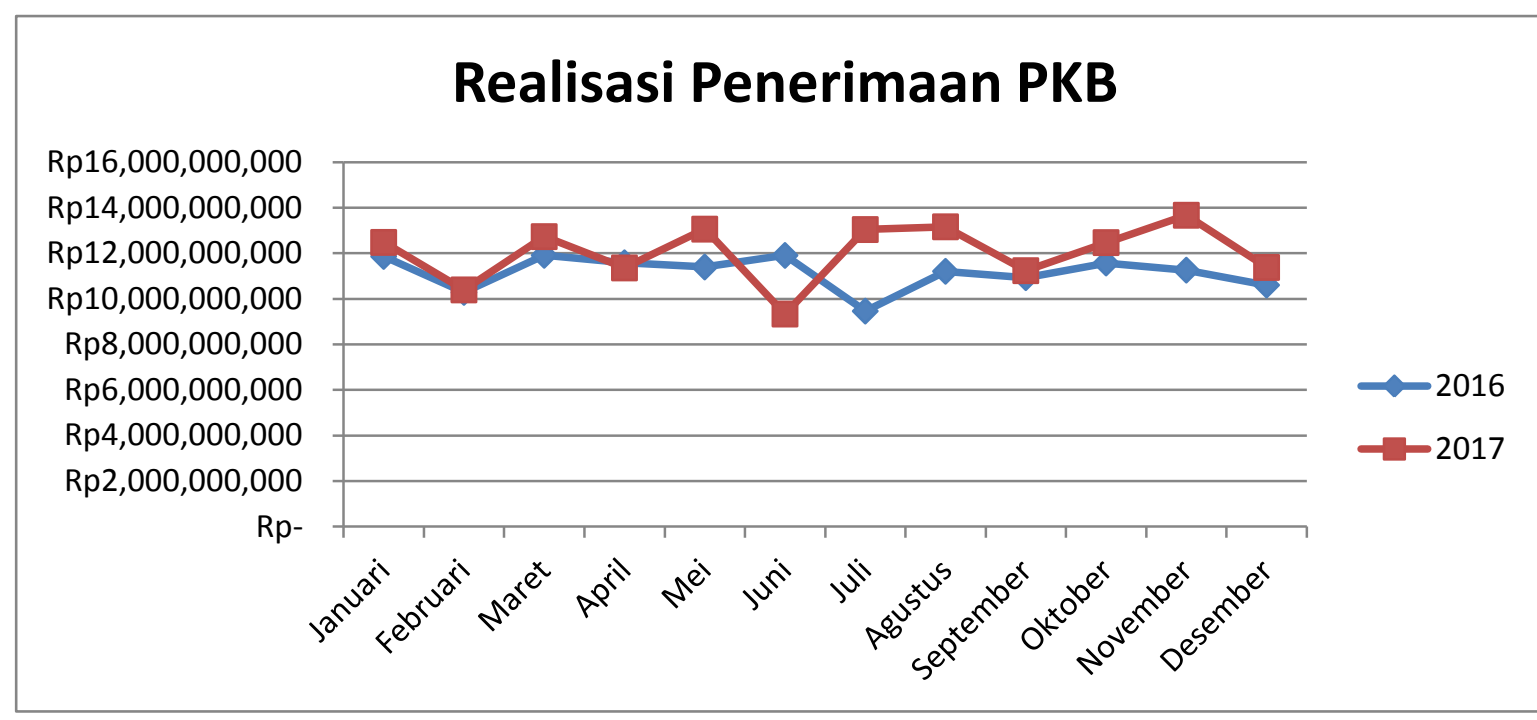

Berdasarkan Grafik 4.5 terlihat bahwa realisasi penerimaan PKB selama bulan September - Desember 2017 atau bulan di mana sedang berlangsungnya program keringanan mengalami peningkatan dibandingkan dengan bulan yang sama pada tahun 2016. Dan peningkatan tertinggi terjadi pada bulan November yang terjadi peningkatan sebesar Rp. 2.409.736.657 dari Rp. 11.260.453.908 di tahun 2016 menjadi Rp. 13.670.190.565 di tahun 2017.

Tabel 4.4 Perbandingan Realisasi PKB 2016 dan 2017 Selama 4 Bulan

\begin{tabular}{|c|c|c|}
\hline Bulan & $\mathbf{2 0 1 6}$ & $\mathbf{2 0 1 7}$ \\
\hline September & Rp. 10.929 .487 .752 & Rp. 11.236.873.121 \\
\hline Oktober & Rp. 11.572 .736 .123 & Rp. 12.469.620.426 \\
\hline November & Rp. 11.260 .453 .908 & Rp. 13.670.190.565 \\
\hline Desember & Rp. 10.603 .857 .986 & Rp. 11.379 .024 .576 \\
\hline Total & Rp. 44.366 .535 .769 & Rp. 48.755.708.688 \\
\hline Rata-rata & Rp. 11.091 .633 .942 & Rp. 12.188 .927 .172 \\
\hline
\end{tabular}

Tabel 4.4 membandingkan realisasi PKB selama 4 (empat) bulan yang berlangsung program keringanan di tahun 2017 dan bulan yang sama pada tahun 2016 yang tidak ada program keringanan. Di tahun 2016 realisasi PKB sebesar Rp. 44.366.535.769 dan meningkat sebesar Rp. 4.389.172.919 di tahun 2017 menjadi Rp. 48.755.708.688. Perbedaan nilai ratarata penerimaan PKB saat program keringanan dan saat tidak berlangsung program keringanan yaitu terdapat selisih Rp. 1.097.293.230, maka dapat disimpulkan bahwa program keringanan berdampak positif terhadap peningkatan penerimaan PKB walaupun tidak memberikan implikasi yang besar. Karena jika realisasi PKB dibandingkan dengan 4 (empat) bulan sebelum dilaksanakan program keringanan yaitu bulan Mei-Agustus dan bulan yang sedang berlangsung program keringanan yaitu bulan September-Desember maka perbedaannya hanya sebesar Rp. 156.577.588 yaitu Rp. 48.599.131.100 di bulan MeiAgustus dan Rp. 48.755.708.688 di bulan September-Desember. Jadi program keringanan meningkatkan penerimaan pajak kendaraan bermotor di UPTD Samsat Manado walaupun implikasinya tidak terlalu besar.

Ini disebabkan oleh proses keputusan untuk pemberian keringanan yang cukup panjang karena verifikasi berkas dan penetapan keringanan dilakukan oleh kantor pusat 
(BP2RD) yang menanggulangi seluruh berkas dari wajib pajak yang berasal dari 10 UPTD Samsat yang terdapat di Provinsi Sulawesi Utara maka membutuhkan waktu yang cukup lama untuk memprosesnya jadi banyak wajib pajak yang tidak memanfaatkan program ini sesuai dengan hasil wawancara yang dilakukan dengan Ibu Aprine selaku Kepala Seksi Pelayanan PKB, BBNKB dan PAP ketika ditanya tentang bagaimana respon masyarakat terhadap program keringanan, menyatakan:

"Jadi keringanan tersebut waktu tahun 2015 hanya Kepala UPT yang tanda tangan jadi tidak ribet. Wajib pajak hanya memasukkan persyaratan lalu kami buat perhitungan dan K.UPT tanda tangan langsung bayar. Kalau ini lumayan lama, ada sekitar 1 sampai 2 minggu prosesnya itu yang membuat masyarakat sedikit mengeluh dan akhirnya memutuskan membayar normal. Ada beberapa yang bayar normal karena lama menunggu SK."

Grafik 4.6 Jumlah Unit Kendaraan Bermotor yang Membayar PKB di UPTD Samsat Manado

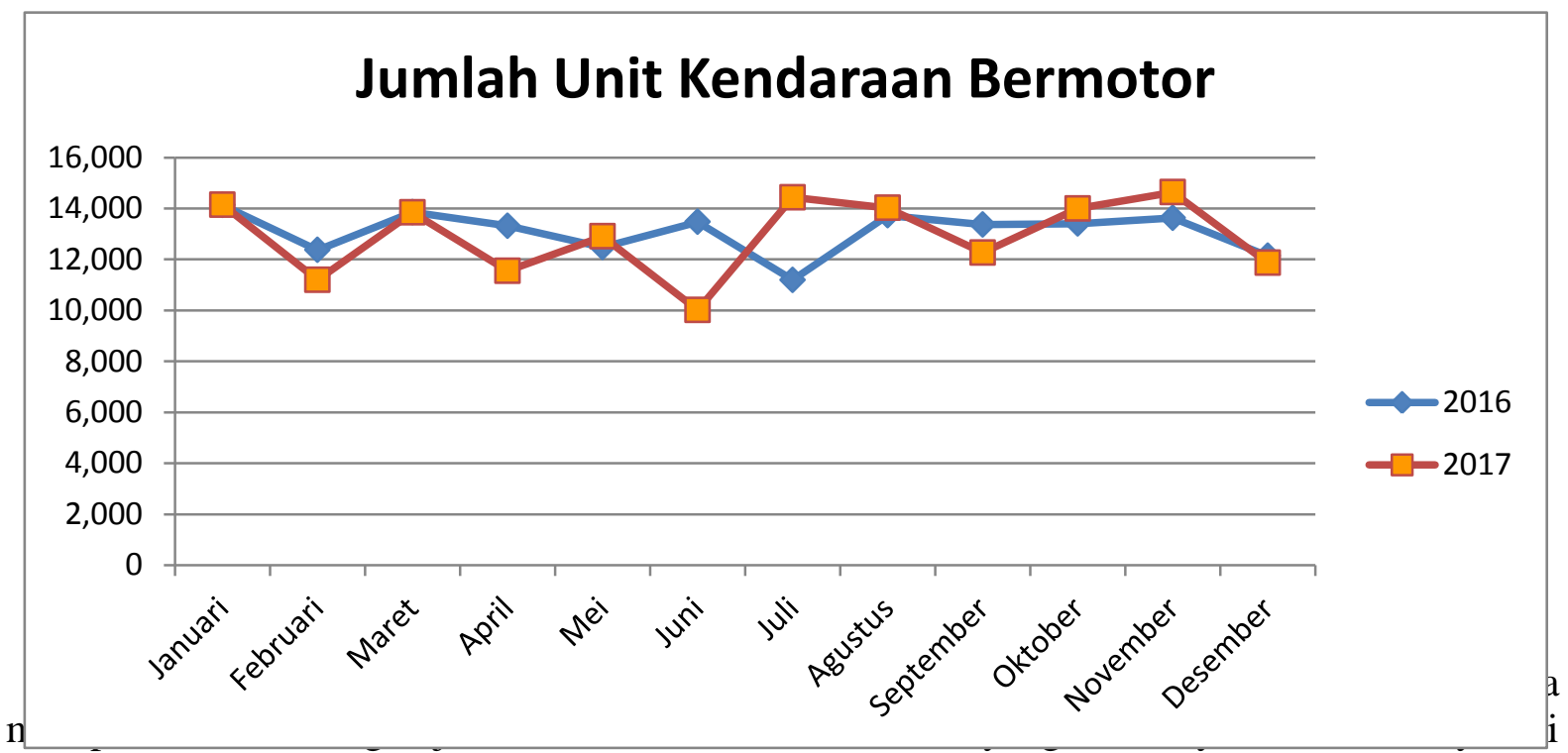

tahun 2017 yaitu sebanyak 14.639 unit kendaraan bermotor, yang meningkat sejumlah 1.011 unit dari bulan November 2016 yang hanya berjumlah 13.628 unit. Jika dilihat secara keseluruhan jumlah unit kendaraan bermotor yang membayar PKB antara 2016 dan 2017, unit terbanyak adalah di tahun 2016 yang berjumlah 157.087 unit dan di tahun 2017 hanya mencapai 154.875 unit kendaraan bermotor. Namun jika dilihat dari total realisasi PKB, realisasi tertinggi terjadi di tahun 2017 yaitu sebesar Rp. 144.314.472.560, yang meningkat sebanyak Rp. 10.335.458.333 dari tahun 2016 yang hanya sebesar Rp. 133.979.014.227.

Kontribusi dari segi jumlah unit kendaraan bermotor yang membayar pajak dengan mengikuti program keringanan yaitu hanya sebesar $0,771 \%$ atau 1.191 unit dari total jumlah unit yang membayar PKB di tahun 2017 yang berjumlah 154.875 unit kendaraan bermotor. Sedangkan untuk kontribusi dari segi total realisasi, program keringanan memberi kontribusi sebesar 2,028\% dari total realisasi di tahun 2017. Dari hasil tersebut dapat ditarik kesimpulan bahwa kemungkinan terbesar kendaraan bermotor yang mengikuti program keringanan adalah kendaraan bermotor yang sudah tua atau yang sudah lama menunggak pajak karena dari segi unit kendaraan bermotor program keringanan hanya memberi kontribus sebesar $0,771 \%$ sedangkan dari segi realisasi penerimaan berkontribusi sebesar 2,028\%. Hal ini juga sema dengan kutipan hasil wawancara dengan Ibu Aprine selaku Kepala Seksi Pelayanan PKB, BBNKB dan PAP yang mengatakan:

"Sebelum keringanan kendaraan yang datang membayar adalah kendaraan yang hanya menunggak rata-rata 1 sampai 2 tahun dan kendaraan-kendaraan yang 
sudah lama tidak membayar pajak seperti ada yang 5 tahun, 7 tahun nah mereka keluar saat keringanan ini."

"Yang mengikuti program keringanan banyak dari kendaraan yang sudah tua, seperti mobil hartop yang sudah 7 tahun tidak membayar pajak. Paling banyak mobil-mobil tua yang keluar."

Tabel 4.7 dapat diketahui bahwa juga tidak semua dari wajib pajak yang permohonan keringanannya telah disetujui dan dikeluarkan SK keringanan datang merealisasikan keringanan mereka.

Tabel 4.7 Realisasi Keringanan Tahun 2017

\begin{tabular}{|c|c|c|c|}
\hline & SK Yang Dikeluarkan & $\begin{array}{c}\text { Realisasi SK Yang } \\
\text { Dikeluarkan }\end{array}$ & Yang Tidak Membayar \\
\hline Rp. & Rp. 3.566.334.764 & Rp. 2.926.532.911 & Rp. 639.801.853 \\
\hline Unit & 1.487 & 1.191 & 296 \\
\hline \multicolumn{2}{|c|}{ Persentase } & $82,06 \%$ & $17,94 \%$ \\
\hline
\end{tabular}

Grafik 4.7 Realisasi Keringanan Tahun 2017

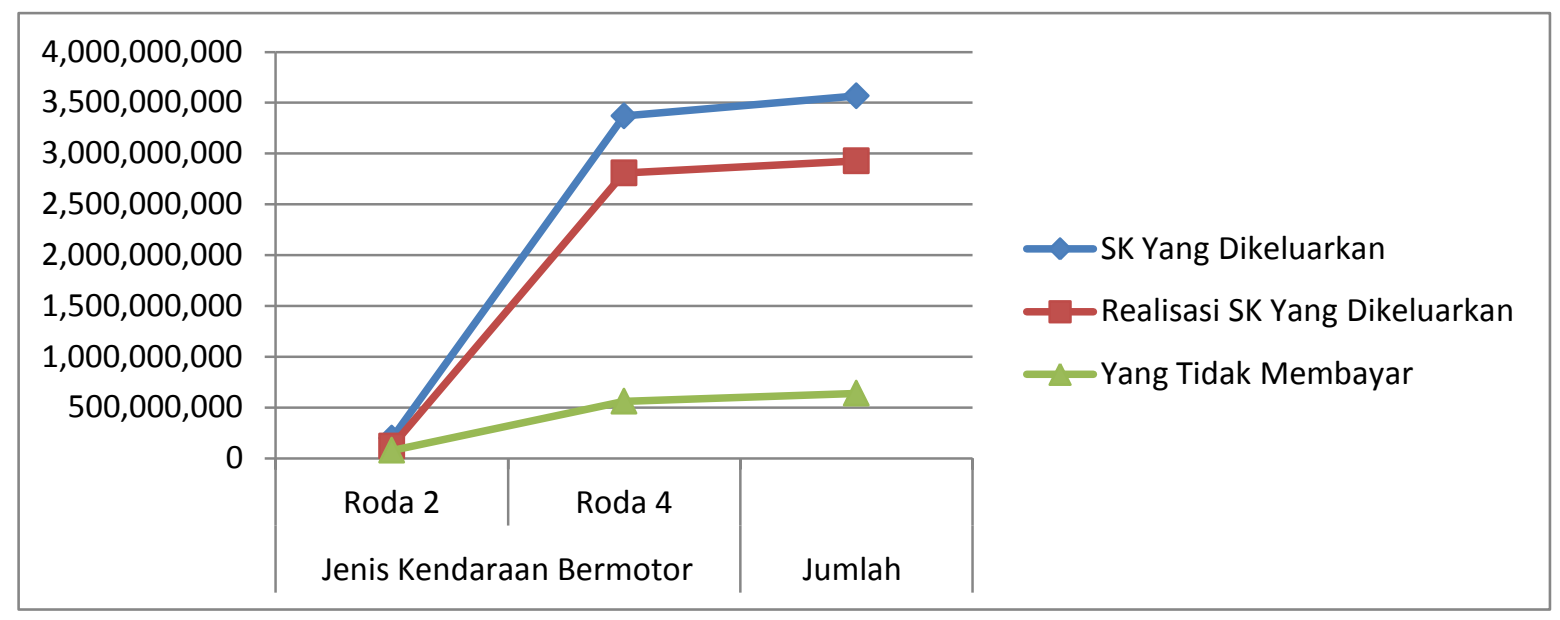

Penyebab dari banyak wajib pajak yang tidak datang membayar keringanannya adalah akibat dari kondisi keuangan yang tidak mencukupi karena program keringanan ini berlangsung pada akhir tahun yang mendekati perayaan Natal dan waktu pembayaran hingga awal tahun di mana saat-saat tersebut masyarakat dalam hal ini wajib pajak memiliki pengeluaran yang lebih besar jika dibandingkan dengan waktu-waktu yang lain sehingga tidak dapat membayar keringanan tersebut walaupun beban pajak mereka menjadi lebih ringan dengan adanya program keringanan, Bapak Ronny selaku Kepala Seksi Pelayanan Sengketa DLL PAD dalam kutipan wawancara mengatakan:

"Ada yang terima SK 1.487 dengan rincian roda 41.063 dan roda 2 424, itu juga yang sudah terima SK itu tidak membayar semua, ada yang datang membayar dan ada yang tidak. Kendala mereka tidak membayar karena mungkin mereka juga belum punya uang, kami juga kan tidak memaksakan mayarakat. Ketika masyarakat tidak punya uang dan kami memaksakan walaupun sudah memberikan keringanan tapi kalau mereka tidak punya uang. Banyak yang seperti itu, yang sudah kami hubungi dan mengatakan bahwa sudah boleh datang membayar tapi mereka mengatakan bahwa mereka masih sementara mengumpulkan uang. Ada yang mungkin pertimbangan lain atau lupa walau sudah dihubungi dan lupa sampai batas waktu tidak membayar." 
Hasil penelitian menunjukkan bahwa penerimaan PKB meningkat dengan adanya program keringanan walaupun implikasinya tidak terlalu besar. Hal ini dapat dilihat dari kontribusi penerimaan PKB dari program keringanan hanya sebesar 2,028\% atau Rp. 2.926.532.911 dari total penerimaan PKB tahun 2017 yang sebesar Rp. 144.314.472.560. Tidak tertalu besar implikasi dari keringanan terhadap penerimaan PKB salah satunya disebabkan karena waktu tunggu SK keringanan yang memakan waktu yang cukup lama karena SK tersebut diproses dan dikeluarkan oleh BP2RD bagian pajak dan harus ditandatangani oleh Kepala Badan membuat wajib pajak malas untuk menunggu. Sama halnya dengan apa yang dikatakan oleh Ibu Aprine ketika ditanya apakah program keringanan meningkatkan penerimaan PKB di Samsat Manado, menyatakan:

"Meningkatkan tapi tidak terlalu signifikan karena waktu itu proses atau mekanisme surat keputusan untuk keringanan lumayan panjang. Jadi dari sini hanya dibuat perhitungan setelah itu dibawa ke kantor pusat makanya banyak dari wajib pajak yang karena sudah lama dan mereka sudah tidak mau menunggu lama akhirnya mereka langsung membayar. Tapi ada juga peningkatan walaupun tidak signifikan dibandingkan tahun-tahun sebelumnya. Kalau tahun sebelumnya SK keringanan hanya ditanda-tangani oleh Kepala UPT."

Beberapa faktor lain yang menyebabkan masih kurangnya kontribusi program keringanan terhadap realisasi PKB adalah seperti kurangnya sosialisasi dari pemerintah ataupun BP2RD dan UPTD Samsat sebagai pelaksana teknis pemungutan PKB. Kurangnya sosialisasi dari BP2RD dan UPTD Samsat karena program keringanan ini tidak direncanakan dari awal tahun jadi tidak ada persiapan matang yang dilakukan dan pihak UPTD Samsat sendiri baru mengetahui adanya kebijakan keringanan PKB dari pemerintah daerah $\mathrm{H}-1$ sebelum program keringanan berlaku. Dan sosialisasi dilakukan ketika program keringanan sedang berlangsung yaitu dengan bekerjasama dengan pihak ketiga yang mengadakan kontes mobil di pusat perbelanjaan dengan membagikan selebaran dan melalui sosial media seperti facebook dan website. Seperti yang dikatakan Ibu Aprine yang merasa juga bahwa waktu sosiaisasi program keringanan tidak terlalu lama menyebabkan banyak masyarakat yang tidak mengetahui program keringanan ini.

"Untuk sosialisasi kami hanya karena program ini tidak direncanakan dari awal tahun seperti yang saya katakan tadi jadi kami ada sosialisasi waktu itu lewat facebook, lewat media sosial, lewat website dan turun ke lapangan membagikan selebaran tapi kalau menurut saya waktunya tidak terlalu lama untuk sosialisasi. Dibuktikan dengan banyak warga yang saat saya tanya mareka tidak tahu. Jadi jika selanjutnya akan dibuat kembali diusahakan sosialisasi lebih lama waktunya."

Dari hasil penelitian juga dapat diketahui bahwa dengan adanya program keringanan dapat menghidupkan kembali objek pajak yang telah lama menunggak pajak. Objek pajak yang menunggak pajak yang biasanya datang membayar pajak adalah yang hanya menunggak sekitar 1 sampai 2 tahun tapi dengan diberikannya keringanan pokok pajak dan penghapusan denda $100 \%$ bagi objek pajak yang menunggak banyak dari pemilik kendaraan tersebut yang datang untuk memanfaatkan program keringanan ini karena beban pajak mereka yang berkurang.

\section{KESIMPULAN DAN SARAN}

\subsection{Kesimpulan}

Kesimpulan yang dapat ditarik oleh peneliti dari hasil penelitian dan pembahasan yang telah dilakukan yaitu: 
1. Dilihat dari jumlah unit kendaraan bermotor, yang mengikuti program keringanan hanya memberi kontribusi sebesar $0,771 \%$ dari total unit kendaraan bermotor yang membayar pajak selama tahun 2017 sedangakan dari segi realisasi penerimaan berkontribusi sebesar 2,028\% dari total realisasi PKB tahun 2017. Jadi dapat ditarik kesimpulan bahwa kemungkinan terbesar kendaraan bermotor yang mengikuti program keringanan adalah kendaraan bermotor yang sudah tua atau yang sudah lama menunggak pajak.

2. Secara keseluruhan dengan dikeluarkannya Peraturan Gubernur Nomor 42 Tahun 2017 tentang pemberian keringanan PKB, meningkatkan penerimaan PKB di UPTD Samsat Manado walaupun tidak terlalu besar implikasinya terhadap penerimaan PKB di tahun 2017. Hal ini dapat dilihat dari kontribusi penerimaan dari keringanan hanya sebesar 2,028\% atau Rp. 2.926.532.911 dari total realisasi penerimaan PKB tahun 2017 sebesar Rp. 144.314.472.560. Hal ini disebabkan karena kurangnya waktu sosialisasi program keringanan kepada masyarakat jadi banyak juga masyarakat yang tidak mengetahui adanya program keringanan PKB. Sosialisasi yang dilakukan hanya melalui media sosial seperti facebook dan website dan membagikan selebaran di salah satu pusat perbelanjaan yang sedang melakukan kontes mobil.

\subsection{Saran}

Saran yang dapat dikemukakan peneliti yang berhubungan dengan penelitian yang telah dilakukan adalah:

1. Bagi Pemerintah Daerah ketika mengambil ataupun mengeluarkan kebijakan seperti mengeluarkan Peraturan Gubernur tentang Keringanan ini kiranya dapat menyusun perencanaan atau mempersiapkan diri dengan baik terlebih dahulu sehingga kebijakan yang dilakukan dapat terlaksana secara efektif dan memberi dampak yang optimal bagi pendapatan asli daerah.

2. Bagi BP2RD sebagai badan pengelola dan UPTD Samsat sebagai pelaksana teknis pemungutan pajak daerah khususnya PKB ketika di masa yang akan datang kembali dikeluarkan kebijakan seperti ini kiranya dapat lebih meningkatkan sosialisasi kepada masyarakat dan juga dapat membina kerjasama dengan pihak-pihak yang berkaitan untuk mengoptimalkan penerimaan daerah dari kebijakan yang telah dikeluarkan tersebut seperti kerjasama dengan pihak kepolisian untuk melakukan penertiban atau razia kepada pengendara kendaraan bermotor yang belum membayar pajak ataupun yang telah menunggak pajak dan diarahkan atau diberitahu bahwa sedang berlangsung program keringanan PKB. Dan bentuk kerjasama lainnya yang dapat mengoptimalkan kebijakan yang telah dikeluarkan pemerintah daerah.

3. Bagi BP2RD dan UPTD Samsat kiranya juga dapat meningkatkan kualitas pelayanan publik sehingga wajib pajak tidak menjadikan kualitas pelayanan publik yang kurang baik sebagai alasan untuk tidak membayar pajak ataupun untuk tidak memanfaatkan program keringanan yang ada ataupun untuk tidak melaksanakan kewajibannya sebagai wajib pajak.

\section{DAFTAR PUSTAKA}

Apsari, N. D. 2012. Pengaruh Insentif Pajak BBNKB Terhadap Jumlah Wajib Pajak Kendaraan Bermotor yang Terdaftar di Surabaya Barat. Jurnal Akuntansi Unesa. Universitas Negeri Surabaya. Surabaya.

Burton, I. 2013. Hukum Pajak. Selemba Empat. Jakarta.

Ekasari, L. D. dan Akbari F. 2017. Tingkat Efektivitas Penerapan Pemutihan Pajak Kendaraan Bermotor Terhadap Peningkatan Penerimaan Pajak Daerah (Studi pada Unit Pelaksana Teknis Dinas Pendapatan Provinsi Jawa Timur Malang Utara dan Batu Kota). Jurnal Optima. Universitas Tribhuwana Tunggadewi Malang. Malang. 
Hasannudin dan Wokas H. R. N. 2014. Analisis Efektivitas dan Kontribusi Pajak Kendaraan Bermotor Terhadap Penerimaan Pendapatan Asli Daerah di Provinsi Maluku Utara. Jurnal Accountability. Universitas Sam Ratulangi Manado. Manado.

Hery. 2014. Akuntansi Pajak. Grasindo. Jakarta.

Inggrini, R., Morasa J. dan Mawikere L. 2018. Analisis Penerimaan Pajak Bea Balik Nama Kendaraan Bermotor di Sulawesi Utara. Jurnal Riset Akuntansi Going Concern. Universitas Sam Ratulangi Manado. Manado.

Mardiasmo. 2011. Perpajakan. Andi. Yogyakarta.

Mardiasmo. 2016. Perpajakan. Andi. Yogyakarta.

Peraturan Daerah Provinsi Sulawesi Utara Nomor 7 Tahun 2011 Tentang Pajak Daerah.

Peraturan Gubernur Sulawesi Utara Nomor 42 Tahun 2017 Tentang Tata Cara dan Besarnya Pemberian Keringanan, Pengurangan Pokok serta Pembebasan Denda Pajak Kendaraan Bermotor dan Bea Balik Nama Kendaraan Bermotor.

Pontoh, I., Ilat V. dan Warongan J. D. L. 2018. Analisis Penerimaan Pajak Kendaraan Bermotor (PKB) dan Bea Balik Nama Kendaraan Bermotor (BBN-KB) dalam Peningkatan Pendapatan Asli Daerah Provinsi Sulawesi Utara. Jurnal Goodwill. Universitas Sam Ratulangi Manado. Manado.

Rahayu, S. K. 2010. Perpajakan Teori dan Teknis Perhitungan. Graha Ilmi. Yogyakarta.

Sujarweni, W. 2015. Metodologi Penelitian Bisnis \& Ekonomi. Pusat Baru Press. Yogyakarta.

Sujarweni, W. 2015. Sistem Akuntansi. Pustaka Baru Press. Yogyakarta.

Supriyanto, E. 2011. Akuntansi Perpajakan. Graha Ilmu. Yogyakarta.

Undang-Undang Nomor 16 Tahun 2009 Tentang Ketentuan Umum dan Tata Cara Perpajakan.

Undang-Undang Nomor 28 Tahun 2009 Tentang Pajak Daerah dan Retribusi Daerah.

Waluyo. 2013. Perpajakan Indonesia Edisi Kesebelas Buku 1. Selemba Empat. Jakarta. 